J. Asiat. Soc. Bangladesh, Sci. 38(2): 183-188, December 2012

\title{
EFFECT OF GAMMA RADIATION ON THE SENSORY, CHEMICAL AND MICROBIOLOGICAL CHANGES IN TWO STRAINS OF CLIMBING PERCH (ANABAS TESTUDINEUS, BLOCH 1792)
}

\author{
SOUMITRA CHAKRABORTY ${ }^{1}$, MD. GHULAM MUSTAFA ${ }^{1}$, \\ MD. ZAHANGIR ALAM ${ }^{2}$ AND MESHKATUL JANNAT ${ }^{1}$ \\ Department of Fisheries, University of Dhaka, Dhaka-1000 \\ Food Technology Division, Institute of Food and Radiation Biology, \\ Atomic Energy Commission, Savar, Dhaka, Bangladesh
}

\begin{abstract}
The quality of gamma irradiated climbing perch was assessed in respect of sensory (organoleptic score), biochemical (TMA and TVN) and microbiological (TBC, TMC, TYC, TCC and Salmonella) tests. Two different doses of gamma irradiation (2 kGy and 6 $\mathrm{kGy})$ were applied while preserving at $-20^{\circ} \mathrm{C}$. The quality changes were observed for 60 days storage period at six time intervals $(1,7,15,30,45$ and 60 days). It was found that the quality of all fish deteriorated with the progress of storage period. The values of all the parameters assessed were higher in non-irradiated fish than that of irradiated fish. No significant differences were observed among the parameters of Thai and Indigenous strain. The most desirable condition for both strains was found in samples treated with 6 kGy irradiation.
\end{abstract}

Key Words: Climbing Perch, Gamma irradiation, Refrigeration, Sensory changes, Chemical changes, Microbiological changes

\section{Introduction}

'Fisheries' is a vital sector contributing substantially to the economy of Bangladesh. It is a major provider of employment next only to agriculture and a large amount inexpensive wholesome protein food to the mass. After landing the catch passes through different marketing chains and it often takes a considerable portion of the normal shelf life of a tropical fish species. Climbing perch is one of the common species found in Bangladesh. Due to increasing demand of this high quality fish, there is an obvious need for development of new technologies and efficient fish preservation methods which permit shelf life extension of these products.

Food irradiation has been used for the purposes of inhibition of sprouting, destruction of food borne insects and parasites, delay of physiological ripening and extension of shelf life or improvement of food qualities (Kim et al. 2005). Though the establishment cost of food irradiation plant is very high, the operational cost is lower than most of other preservation methods. The application of radiations preservation to fishery products has been exploited by Nickerson et al.(1954) and Proctor et al.(1960). Irradiation at a dose of up to $10 \mathrm{kGy}$ has been used in both animal and vegetable foods as an effective, safe and 
economical method of food preservation posing no nutritional, toxicological or microbiological problems (WHO 1994).

Food irradiation, in combination with good refrigeration and handling practices, might provide a means to increase fish product shelf life. In Bangladesh the knowledge about the shelf life of refrigerated gamma-irradiated fish product is almost absent.

Therefore, The present study was carried out to observe the effect of different dose of gamma-radiation (2 kGy and $6 \mathrm{kGy}$ ) followed by refrigeration (at $-20^{\circ} \mathrm{C}$ ) on degutted fresh Climbing perch (Anabas testudineus) of two strains (Thai and Indigenous).

\section{Materials and Methods}

All investigations were carried out in the laboratory of Food Technology Division, Institute of Food and Radiation Biology (IFRB), Atomic Energy Research Establishment (AERE), Savar, Dhaka.Fresh climbing perch used in this experiment were collected from the Kawran Bazar and New Market Kancha Bazar.

Irradiation: Except non-irradiated (control) samples the other samples were subjected to irradiate in a 50,000 curie Co-60 source supplied by the Atomic Energy of Canada Ltd. The samples were subjected to irradiate in $2 \mathrm{kGy}$ and $6 \mathrm{kGy}$ doses and the dose rate at the time of treatment was $2 \mathrm{kGy} /$ hour. Fish samples were maintained at $2 \pm 2^{\circ} \mathrm{C}$ during irradiation by using sealed ice covering. Control fish samples were kept in polystyrene boxes with sealed ice at the ambient temperature of $18-20^{\circ} \mathrm{C}$. After the radiation treatment all samples were stored at $-20^{\circ} \mathrm{C}$ temperature and were examined at $0,7,15$, 30,45 and 60 days of storage periods.

Sensory analysis: Sensory evaluation for the detection of freshness or shelf-life of the stored fish and consumers acceptance were performed with high degree of reliability by organoleptic evaluation. Nine point hedonic scales were used for sensory evaluation by five judges following the method of Miyauchi et al.(1964).

Chemical analysis: Conway micro-diffusion technique (Conway and Byrne 1933) was employed for the estimation of TVN and TMA.

Microbial analysis: To determine the microbial changes total bacterial count (TBC), total mould count (TMC), total yeast count (TYC), total Salmonella count and total coliform count (TCC) were determined by decimal dilution technique followed by pour plate method (Sharf 1966).

\section{Results and Discussion}

Sensory Assessment: Average score of initial sensory investigation was 8.88 for Thai strain and 9.00 for indigenous strain which were decreased slowly with the progress of storage period (Fig. 1). At 60 days of storage, the sensory score of non-irradiated and irradiated samples were $5.46 \pm 0.22,6.43 \pm 0.29(2 \mathrm{kGy})$ and $6.72 \pm 0.26$ (6 kGy) 
respectively in Thai strain whereas in indigenous strain, the sensory score of nonirradiated sample was $5.94 \pm 0.12$ and in irradiated sample it was $6.65 \pm 0.16(2 \mathrm{kGy})$ and $7.12 \pm 0.12(6 \mathrm{kGy})$. Miyauchi et al.(1964) suggested that the average sensory score of 5 might be accepted in case of organoleptic test. So the samples were within acceptable level throughout the experiment. It was also observed that the sensory score of irradiated samples was higher than that of non-irradiated samples in both strains.

Chemical Analysis: TVN content of non-irradiated and irradiated ( 2 kGy and 6 kGy) climbing perch are shown in Fig. 2. At the beginning of storage, the TVN values did not vary significantly among non-irradiated and irradiated samples in both strains. Whereas significant differences $(\mathrm{p}<0.05)$ were observed among non-irradiated and each irradiated samples after 60 days of storage in both strains. It was also observed that TVN values increased with the progress of storage period.

Tanikawa (1935), Yamamura (1938), Shewan (1975), Stansby et al.(1944) and Ota (1985) also found that the total volatile nitrogen (TVN) increased with the increase of time during spoilage and all of them suggested that $30 \mathrm{mg} \mathrm{N} / 100 \mathrm{~g}$ of fish muscle should be taken as the upper limit for acceptability. In the current study the sample of both strains that were irradiated at $6 \mathrm{kGy}$ dose remains within acceptable level throughout the experiment. Moreover, the TVN values were lower in irradiated samples than those of non-irradiated samples in all cases after one week of storage.

The TMA values were also increased with storage period. After 60 days of storage significant differences $(\mathrm{p}<0.05)$ were found among the TMA values of non-irradiated and irradiated (2 kGy and $6 \mathrm{kGy}$ ) samples in both strains. But Baldwin (1957)and De and Mea (1966) suggested that the presence of TMA in freshwater fish does not give a proper indication of spoilage. So the higher TMA value of the current study did not surely indicate the spoilage of the samples.

Microbiological Analysis: Total Bacterial Count (TBC) presented in Table 1 shows that bacterial growths were greatly affected by the radiation. The initial bacterial load in control was maximum in both strains $(1600.00 \pm 76.38 \mathrm{cfu} / \mathrm{g}$ in Thai strain and $83.33 \pm$ $33.33 \mathrm{cfu} / \mathrm{g}$ in indigenous strain) followed by $2 \mathrm{kGy}$ irradiated samples $(50.00 \pm$ $28.87 \mathrm{cfu} / \mathrm{g}$ in Thai and $83.33 \pm 33.33 \mathrm{cfu} / \mathrm{g}$ in indigenous strain). At $6 \mathrm{kGy}$ radiation the samples were sterilized resulting very low bacterial growth $(16.67 \pm 16.67 \mathrm{cfu} / \mathrm{g}$ both in Thai and indigenous strain). This value increased gradually from the beginning upto 60 days of storage in both strains. According to international commission on the microbiological specification of foods guideline, acceptable total bacterial count for fish is $10^{6} \mathrm{cfu} / \mathrm{g}$. Shewan (1975) also recommended that the microbial limit is 1 $10^{6} \mathrm{cfu} / \mathrm{g}$ of fish flesh for tropical fishes. Hence, TBC values in the present investigation suggest that the irradiated samples remain acceptable after 60 days. 
Moreover, significant differences were found $(\mathrm{p}<0.05)$ among control and each irradiated samples after 60 days of storage in both strains.

In case of total mould count (TMC) it was also found that the population increased with the increase of storage period and significant differences were found $(p<0.05)$ among control and each irradiated samples after 60 days of storage in both strains. Vinh et al. (1993) suggested that mould count of raw fish ranged from 27-1500 cfu/g can be considered as acceptable. Thus TMC in the present study is between the expectable levels.

Total yeast count or TYC also showed such gradual increasing trend with the increasing storage period.

During investigation of 60 days storage period no Coliform and Salmonella were found, indicating the absence of fecal contamination.

The current study showed the synergistic effect of two preservation method, food irradiation and freezing in low temperature on Climbing perch (Anabas testudineus) to extend its shelf life. Irradiation at low dose is effective to extend the shelf-life of fish and fishery product for a few days but slightly higher dose with low temperature preservation, fish can be maintained at highest quality up to a considerable long period.
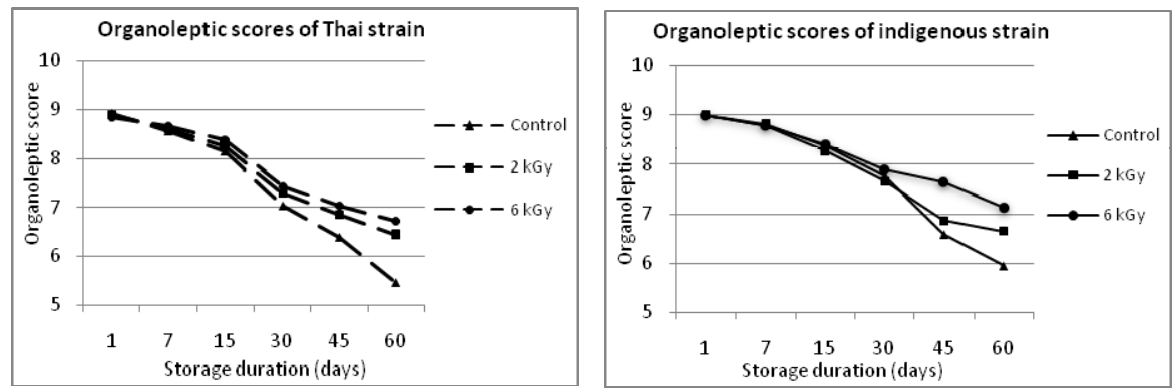

Fig. 1. Line charts of organoleptic scores of Thai and indigenous strains at six storage durations.
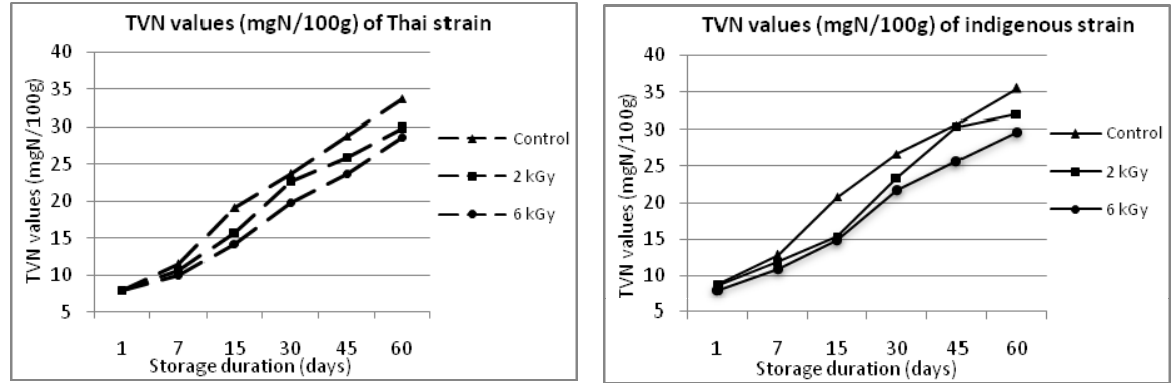

Fig. 2. Line charts of TVN values of Thai and indigenous strains at six storage durations. 


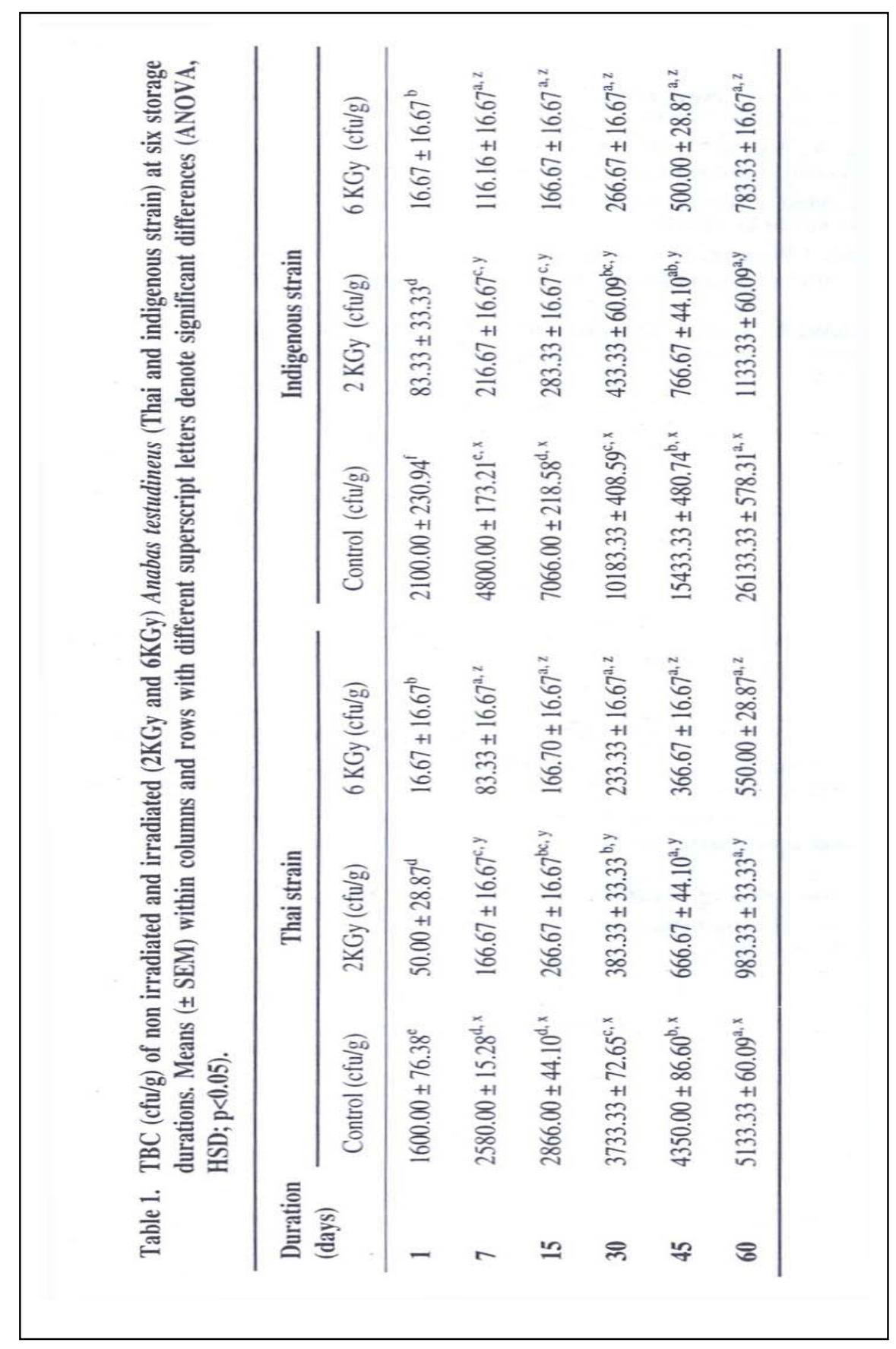




\section{References}

Baldwin, E. 1957.Dynamic aspects of biochemistry.Cambridge University Press. London and New York, $3^{\text {rd }}$ Edn. P. 298.

Conway, E.J. and A. Byrne. 1993. An Absorption Apparatus for the Micro-determination of Certain Volatile Substance. Biochemistry. 27: 419-429

De, H.N. and A.R. Mea. 1966. Bio-chemical and nutritive studies on East Pakistan Fishes. J. Sci. Res. Part xiii.3(2):110-119.

Kim, J.H., H.J. Ahn, J.W. Lee, H.J. Park and G.H. Ryu. 2005. Effects of gamma irradiation on the biogenic amines in pepperoni with different packaging conditions. Food Chem.89: 199205.

Miyauchi, D.T., M.W. Eklund, J. Spinelli and N.V. Stoll. 1964. Irradiation Preservation of Pacific Coast Shell fish Storage life of icing crab meats at $330^{\circ} \mathrm{F}$ and $420^{\circ} \mathrm{F}$. Food Technology. 18:928-932.

Nickerson, J.T.R., E. Lokart, B.E. Proctor and J.J. Licciardello. 1954. Ionizing radiation for control of fish spoilage. Food Technology.8:32.

Ota, F. 1985. Carbonyl compound in fish as related to deterioration. Bull Japan Soc. Sci. Fisheries.24(5): 334-337.

Proctor, B.E., S.A. Goldblith, J.T.R. Nickerson and F.R. Farkas. 1960. Evaluation of the technical economic and practical feasibility of radiation preservation of fish. USAEC.Rpt. No.NYO-9182.

Sharf, J.M. 1966. In: Recommended Methods for Microbiological Examination of Foods $\left(2^{\text {nd }}\right.$ Ed.).American Public Health Association (AMHA).New York, pp.180.

Shewan, J.M. 1975. The bio-deterioration of certain proteineceous food stuffs at chill temperature. In: "Industrial aspects of Bio-chemistry"'.Federation of European Bio-chemistry society, North-Holland pub.Co. Amsterdam.pp. 475.

Stansby, M.E., R.W. Harison, J. Dassow and M. Starter. 1944. Determining Volatile Bases in Fish, Composition of Certain Methods. Ind. Eng. Chem. 16: 593-596.

Tanikawa, E. 1935.Studies on measuring fisheries of fish and shellfish meat.J. Sco. Ind. Fish (Japan) 3:267-296.

Vinh, P.Q., M.D. Alur,.and P.M. Nair. 1993. Sensory attributes of non irradiated and irradiated semi dried fish during ambient temperature storage. Fish Technol. Kochi .30(2): 161163.

WHO 1994.Wholesomeness of Irradiated Food.WHO, Geneva, Switzerland.

Yamamura, Y. 1938. The putrefactive degree and $\mathrm{pH}$ value of fish muscle. Bull. Japan Soc. Sci. Fish. J. 2: 101-108. 